\title{
A METHOD FOR DISAGGREGATING CLAY CONCRETIONS AND ELIMINATING FORMALIN SMELL IN THE PROCESSING OF SEDI- MENT SAMPLES
}

\author{
Tomas Cedhagen
}

\section{SARSIA}

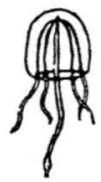

Cedhagen, Tomas 198911 15. A method for disaggregating clay concretions and eliminating formalin smell in the processing of sediment samples. - Sarsia 74:221-222. Bergen. ISSN $0036-4827$.

\begin{abstract}
A complete handling procedure for processing sediment samples is described. It includes some improvements of conventional methods. The fixed sediment sample is mixed with a solution of the alkaline detergent $\mathrm{AJAX}^{\circledR}$ (Colgate-Palmolive). It is kept at $80-90^{\circ} \mathrm{C}$ for $20-40 \mathrm{~min}$. This treatment facilitates subsequent sorting as it disaggregates clay concretions and faecal pellets but leaves even fragile organisms clean and unaffected. The ammonia in the detergent eliminates the formalin smell.
\end{abstract}

Tomas Cedhagen, University of Göteborg, Department of Zoology, Division of Morphology and Ecology, P.O.Box 25059, S-400 31 Göteborg, Sweden.
In the processing of marine soft bottom samples, two well-known problems are often encountered. First, numerous clay concretions and faecal pellets clog the sieve which considerably prolongs the sieving time and consequently also prevents a more careful treatment of the material. Second, fixatives such as formalin cause the investigator irritation and sometimes an allergic reaction. Holme \& McINTYRE (1984) and Pfannkuche \& Thiel (1988) reviewed the methods for investigating soft bottom macrofaunas and meiofaunas. Those of the procedures described by them which are of interest in this article fall into two categories: those for disaggregating concretions of clay and faecal pellets, and those for separating animals from the sediment. However, I found none of them to be effective. By using the method described in this paper, these problems are reduced or eliminated.

MurRay (1971) described a method for staining and drying the samples and for separating them by gravity with the help of carbon tetrachloride $\left(\mathrm{CCl}_{4}\right)$. I found that a large part of the specimens of most of the species are destroyed by this treatment, or lost in the handling procedure. The same problem arises if bromoform $\left(\mathrm{CHBr}_{3}\right)$ is used instead of carbon tetrachloride, as described by BoLtovsкoy \& WrIGHT (1976). Ultrasonic treatment, as described by THIEL \& al. (1975) for the dispersion of clay concretions also proved unsuccessful. MELDGAARD \& KNUDSEN (1979) described a method for the dispersion of concretions in samples with a solution of sodium pyrophosphate $\left(\mathrm{Na}_{2} \mathrm{P}_{2} \mathrm{O}_{7} \cdot 10 \mathrm{H}_{2} \mathrm{O}\right)$. I found this method to be suitable only for samples with organisms lacking calcareous structures, because such structures often dissolve after $30 \mathrm{~min}$ in a hot $\left(80-90^{\circ} \mathrm{C}\right)$ solution. Structures made of aragonite are more easily dissolved than structures of calcite. BARNETT (1980) described a method for the dispersion of clay concretions by freezing. I found that this method destroys many fragile forms such as some agglutinated Foraminifera. I also tested the technique of using Ludox-TM, a colloidal silica polymer, as described by Holme \& McInTYre (1984). It did not work at all for samples containing organisms with agglutinated or calcareous tests or shells as the densities of such organisms are often higher than that of Ludox-TM.

I found that solutions of sodium hypochlorite $(\mathrm{NaOCl})$ and hydrogen peroxide $\left(\mathrm{H}_{2} \mathrm{O}_{2}\right)$ are useful for dispersing clay concretions and faecal pellets, but that they oxidize and dissolve the organic parts of the animals. This makes it impossible to determine whether organisms such as Foraminifera were alive or not when they were sampled.

Detergents were found to be useful provided that they are not so acidic that they dissolve calcareous structures such as tests of foraminiferans. The following method was found to solve the problems mentioned above. It was tested on core samples $(5 \mathrm{~cm}$ in diameter, $2-3 \mathrm{~cm}$ deep) from soft, clayey bottoms. All clay concretions and faecal pellets were dispersed so that the residue consisted mainly of clean animals (stained with Rose Bengal or unstained). Foraminifera with a clay test, such as Pelosina BRADY, 1879, remained unaffected.

1. Fix the sediment sample $(40-60 \mathrm{ml})$ in $100-200$ $\mathrm{ml}$ of a $4 \%$ solution of formaldehyde in sea-water, buffered with 1-2 teaspoons of disodium tetraborate (borax, $\mathrm{Na}_{2} \mathrm{~B}_{4} \mathrm{O}_{7} \cdot 10 \mathrm{H}_{2} \mathrm{O}$ ). Rose Bengal, a protoplasmic stain (see PfannkUChe \& Thiel 1988), can be added at this stage or later. Shake the jar to mix the sediment with the buffered fixative. Leave the sample for a minimum of two days but not for 
more than two months because formalin buffered with borax is slightly histolytic.

2. Sieve the fixed sediment sample in fresh water. Animals in the coarser fractions ( $\geq 500 \mu \mathrm{m})$ can be picked out at this stage without any difficulty. Alternatively, the coarser fractions can be treated in the same way as the finer ones (as described below).

3. Mix the finer fractions $(50-500 \mu \mathrm{m})$ with a solution of $5 \mathrm{ml} \mathrm{AJAX}{ }^{\circledR}$ (Colgate-Palmolive, a trademark used world-wide) in $100-200 \mathrm{ml}$ of water. AJAX is a liquid detergent for domestic sanitary use which contains ammonia and therefore has a high $\mathrm{pH}$-value.

4. Leave the sample in an oven at $80-90^{\circ} \mathrm{C}$ for 20-40 $\mathrm{min}$. The time required depends on the size and compactness of the clay concretions. Incubation of the sample for 1-2 hours does not adversely affect the animals.

\section{Sieve the sample again.}

6. Preserve the animals in a mixture of 19 parts of $80 \%$ ethanol and 1 part of glycerol.

The efficiency of this procedure for breaking up sediment aggregates was compared with that of conventional sieving. The original volumes of fixed sediment samples from the Swedish west coast were measured, and sieved through sieves with mesh sizes of $500,300,200$, and $100 \mu \mathrm{m}$. Then the volume of the residue was measured and the residue treated according to the method described above. The volume of the final residue was then measured. The results are summarized in Table 1 . They show that the volume has decreased substantially as almost all aggregates and faecal pellets have dispersed. Only clean organisms and mineral particles are left.

The addition of $\mathrm{AJAX}^{\circledR}$ has the following beneficial effects: It eliminates the smell of formalin, prevents calcareous structures from being dissolved because of its alkalinity, and promotes the dispersion of clay concretions. This detergent is cheap and easily obtainable all over the world. It is also safe to use, unlike some of the highly toxic chemicals $\left(\mathrm{CCl}_{4}, \mathrm{CHBr}_{3}\right.$, and Ludox) mentioned above. The addition of glycerol to ethanol (step 6) also has important advantages. It is easier to obtain good sections of paraffin-embedded specimens when they have been preserved in this way. The glycerol seems to prevent the ethanol solution from turning acid with time and thus from dissolving calcareous struc-
Table 1. Comparison of residues of sediment samples sieved through a $100-\mu \mathrm{m}$ sieve without and with treatment with AJAX.

Gullmarsfjorden

$30 \mathrm{~m} \quad 115 \mathrm{~m}$

Kosterfjorden

$210 \mathrm{~m}$

Original volume

(ml) of fixed sample

178

197

85

Volume (ml) after

sieving without AJAX

29

26

9

Volume (ml) after

sieving with AJAX

22

1,5

3

Nature of residual sediment

Numerous

Few mineral mineral particles

tures. Finally, if the ethanol should accidentally evaporate from a sample jar, the glycerol will remain and reduce the damage done to the animals.

\section{ACKNOWLEDGEMENTS}

I am very much indebted to Dr Anders Warén, Stockholm, for pointing out to me the possible usefulness of ammonia for the elimination of formalin smell from fixed samples, to Dr Stefan Mattson, Göteborg, for valuable discussions and a critical review of the manuscript and to Mr Carl André and Mr Fredrik Pleijel for some comments.

\section{REFERENCES}

Barnett, B.E. 1980. A physico-chemical method for the extraction of marine and estuarine benthos from clay and resistant muds. - Journal of the Marine Biological Association of the United Kingdom 60:255.

Boltovskoy, E. \& R. Wright 1976. Recent Foraminifera. - Junk, The Hague. xvii + 515 pp.

Holme, N.A. \& A.D. McIntyre 1984. Methods for the Study of Marine Benthos. - IBP Handbook 16. Blackwell Scientific Publications, Oxford. xii +387 pp.

Meldgaard, S \& K.L. Knudsen 1979. Metoder til indsamling og oparbejding af prøver til foraminifer-analyser. - Dansk Natur - Dansk Skole. Årsskrift 1979: 48-57.

Murray, J.W. 1971. An Atlas of British Recent Foraminiferids. - Heinemann, London. xii +244 pp.

Pfannkuche, O \& H. Thiel 1988. 9. Sample processing. Pp. 134-145 in: Higgins, R.P. \& H. Thiel (eds). Introduction to the study of meiofauna. Smithsonian Institution Press, Washington D.C., London.

Thiel, H., D. Thistle \& G.D. Wilson 1975. Ultrasonic treatment of sediment samples for more efficient sorting of meiofauna. - Limnology and Oceanography 20:472-473.

Accepted 29 June 1989. 